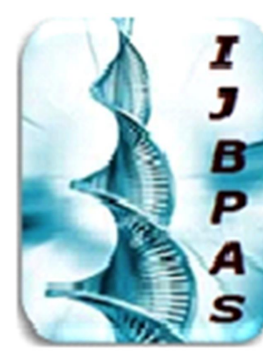

International Journal of Biology, Pharmacy

and Allied Sciences (IJBPAS)

'A B Bridge Betusen Caboratory and QRendo'

Www.jibpas.com

\title{
DYNAMISM IN CUSTOMARY LAND TENURE IN SRI LANKA
}

\section{DHARMASIRI LM}

Senior Professor and Carder Chair, Department of Geography, University of Kelaniya, Sri Lanka

"Corresponding Author: Dr. Lal Mervin Dharmasiri: E Mail: mervin@kln.ac.lk

Received $10^{\text {th }}$ June 2021; Revised 11 ${ }^{\text {th }}$ July 2021; Accepted $20^{\text {th }}$ Aug. 2021; Available online 15 ${ }^{\text {th }}$ Jan. $_{2022}$

https://doi.org/10.31032/IJBPAS/2022/11.1.1073

\begin{abstract}
This paper's focus is to examine and identify the dynamism in customary land tenure in Sri Lanka. Customary tenure is a set of rules and norms that govern community allocation, use, access, and transfer of land and other natural resources. In Sri Lanka, the customary land tenure has been transforming from time to time with a variety of laws and legal systems. In this regard, Vihara and Devalegam tenure system, Literature and a field study was done in respect of the specified programme. The hypothesis of this study was that the "customary land tenure system is static, but one that has been transforming into new order from time to time, thus the customary land tenure system is a dynamic process" which has been proven and further elaborated by the model of dynamism in customary land tenure. It was identified that there is a different relationship between tenure rights and land productivity under the customary tenure system.
\end{abstract}

\section{Keywords: Customary tenure, Land tenure and Vihara and Devalegam}

\section{INTRODUCTION}

This paper's main focus is to examine and identify the dynamism in customary land tenure in Sri Lanka. Land tenure is defined as 'the relationship, whether legally or customarily defined, among people, as individuals or groups, with respect to land'. Land tenure is an institution, i.e., rules invented by societies to regulate behavior. Rules of tenure define how property rights to land are to be allocated within societies. Thereby defining how access is being granted to rights to use, control and transfer land as well as associated responsibilities and restraints. In simple terms, land tenure systems determine who can use what resources for how 
long, and under what conditions (FAO, 2002). The term 'land' refers to land and all related property and natural resources associated with the specified matter. 'Tenure' defines the type of right or ownership and use of land. The tenure systems have been changing from time to time in Sri Lanka where different groups of people have settled in the country from time to time thereby introducing various types of customary laws thus at some point turning to local customary laws later on.

In Sri Lanka, the customary land tenure had been transforming from the Aryan, Dravidians, Moors and more recently the Portuguese, the Dutch and the British leaving a legacy of a variety of laws and legal systems related to land. In the ancient time lands were given to religious institutions under different systems such as Viharagam, Devalegam and Nindagam given by the Kings which stands as a good example. Apart from the facts mentioned in prior, the following customary laws are still practicinged and have taken an important place in social, economic and cultural context thus being categorized into several sections such as Kandiyan Law for the Sinhala community living in upcountry, Thesawalmai Law for the Tamil community living in the North, Muslim Law (Shariya Law), Mukkuvars, Chetties, Parsees and Parawas law for the communities living in the East and Roman and Dutch Law for the people who do not belong to other customary which can be mentioned as different law procedures persisting in Sri Lanka (Dharmasiri, 2009).

Literature reveals that the customary land tenure security situation in most countries are certainly not fair. When customary land management systems are unstable and weakened, the legal statutory systems fail to manage the complex issues in local communities whose livelihood depends on land where Population pressure on land, Government policies, Religious factors, Topography and Commercialization being the cause of the insecurity of land. Therefore, it is an important factor to examine the customary land tenure system and its dynamics on the sustainable land management system in Sri Lanka. Hence in this context, Maintenance of Environmental Sustainability, the Control of Social Conflicts and the Food Security can be mentioned as remedial methods against these vulnerable factors that are being affected by land tenure.

\section{METHODOLOGY}

In respect of the existing literature on land tenure, special attention was paid to Sri Lanka and it has been reviewed in particular that the documents related to historical and legal documents were extensively used for the study. 
A collaborative study has been done with LND Liyanapatabandi, who has done a research on "Recent trends in land tenure on the Vihara and Devalegam: With reference to Nindagam of the Beligala temple in Sri Lanka" where in 2021 it has been incorporated with this study. The temple and 13 land users representing different tenure utilizing land under the temple land (Viharagam and Devalegam) were selected by applying a judgment sample for the study. Qualitative approach has been applied for collection of information related to the study. Based on the information found on the study, a 'model of dynamism of customary land tenure' has been formulated.

Further to more, a hypothesis was developed to understand the fact that the "customary land tenure system is a static, but one which has been transforming into new order from time to time, therefore in conclusion, the customary land tenure system is a dynamic process".

\section{Dynamism of land tenure}

The encounter encapsulates two of the most enduring concepts of land. On one hand, land is simply a form of property that may be traded at will. On the other, land is much more than just a personal private property, and its possession is not (just) a matter for the market forces to determine (Mather, 1986; 2). The literature on land ownership and its origins and evolution is enormous. It is possible to discuss a cycle in which an ancient pattern of communal control or ownership of land gave way to individual private property rights. In the ancient world, the concept of private property rights on land was not known due to a negligible population pressure on ample land which during that period, land being treated as a 'free good' like water and air.

The feeding and living territory of the tribes or groups of individual families defended themselves against other such groups when population grew and competed for the land. As a result, communal land gradually being vested in the hands of the leader of the group where from that point onwards he had the right to control the land on behalf of the community. It should be mentioned that land rights from community to individuals were given an important place according to tenure principles. Land is a fundamental factor of production in the agricultural sector. It has an essential role to play in increasing as well as sustaining agricultural production. The extent to which this role operates is determined in part by methods of land acquisition and arrangements for the ownership and use of land.

\section{Dynamism of land tenure in Sri Lanka}

The tenure system in ancient Sri Lanka was simple. In fact, the King was the absolute lord of the soil and landed property of every description originated from him. The central 
region of Sri Lanka remained under the rule of the Sinhalese Kings for over ninety percent of the period of recorded history since its early beginnings in the $6^{\text {th }}$ century B.C. The King himself was given the honorable title of Maheepathi, Bhupathi, Bhupala, Vathumi and Dharanipathi, indicative of his fundamental function as the supreme lord of the land or 'ruler of the earth'. Ariyapala states, "...the king was the sole owner of land, which was given out to people by his grace either for a payment or in return of some kind of service" (Ariyapala, 1956; 140). He provides very scant supporting evidence to justify his adherence to this theory. Ralph Pieris (1956) mentioned that the King is described as 'Lord of the Soil' and the theory conferred upon the sovereign an unqualified right to an arbitrary seizure of land (Pieris, 1956; 43). 'Portuguese Rule in Ceylon in 1966' written by Abeysinghe (1978) and 'Proprietary and Tenure Rights in Ancient Ceylon' written by Perera also expressed the same view. Researchers like Siriweera (1994) have rejected the theory, in which the King controlled all the land. He argued that the terms such as 'ownership' and 'proprietorship' have not been precisely defined by the writers who have used these terms of expressions such as Maheepathi, Bhupathi and Bhupala are conventional errs of eulogy to denote the king (Mahinda, 1987; 34). Codrington, also argued that "... the king, though having the supreme disposal of land, was bound by the law. "(Codrington, 1938; 5-6). As this argument shows, there is no sound basis for the theory of the king's sole ownership of land. By examining these arguments it is possible to say that in ancient Ceylon land belonged not only to the King but also to private individuals and groups of individuals.

Siriweera (1994) argued that the terms such as 'ownership' can actually be applied meaningfully to problems of ancient land tenure. Numerous references in inscriptions regarding land grants, land sales and other land transactions by individuals and donations and assignments of land by the king may superficially suggest that the existence of ideas of land 'ownership' in pre-modem Sri Lanka, are similar to those prevalent in modem times. Nevertheless, despite a close study of inscriptional and literary evidence, the ideas of land 'ownership' prevalent in ancient days have passed on to the modem scholar - as hazy as ever. The difference between 'ownership' and tenure was so subtle that it is sometimes difficult to know exactly where to draw the line between the two. However, an attempt is made here to classify and understand that the ancient land ownership and tenure are under the land directly controlled by the King and land given to religious institutions are land 
controlled by individuals. The competitive land ownership pattern during the period of ancient Kings can be shown in Figure 01. Land directly controlled by King; Gabadagam (storehouse) and Vidanegam (controlled by regional leaders). According to the first part of the diagram; Land under direct control of the King has been mainly divided into two categories (Abeysinghe, 1978; 44). Gabadagam - These were the villages of the storehouse in the Kandyan period. Crown land (Royal lands), which literally means Gabadagam, was most extensive and granted to the people for the service like civil and military activities (Rajakariya) rendered to the king. Some other Gabadagam were given to people for extracting revenue for the king. At times, Gabadagam was set apart for the holders of office in the service of the king. Besides the king's principle Gabadagam, there were Bisogam also during the period of Kandyan kingdom. The queen's village was known as Bisogam (Pieris, 1956; 50). Nindagam (given to selected officials), Sewa land (given to those who served the king on permanent basis) and the other categories are discussed under the 4.0 of this article.

Land controlled by individuals; Paraveni land (non service tenure), Andeparaveni (share cropping ownership), Otuparaveni (tenancy ownership of less fertile land), Ovitiparaveni (non-service tenancy ownership). The third category of land holdings are comprised of several subtitles as Korelagamand Vidanagam which were under the custodianship of petty of officials who paid periodic tribute to the king with revenue in cash or kind collected from those who occupied such land. Generally, the village settlement with Korelagam and Vidana gam status were more frequent in occurrence in the peripheral part of the kingdom, and it seems that service obligations and taxes of their inhabitants were lighter than those of the royal, manorial and monastic lands (Peiris, 1996; 116). Saramarugam is another type of tenure in which land ownership may change with the service to the royal officials.

The fourth category of the ancient land system referred to the ordinary people who practice different tenure systems. Those systems were also known as non-service tenures. Nonservice tenures were classes of land belonging and permanently alienated by Government on condition of receiving a share of the produce as tax. They generally were called Paraveni lands and were held in fee simple and were free of all obligations. Non-service fields included three types of Paraveni lands (Abeysinghe, 1978;40). Otuparaveni lands (1 $/ 10^{\text {th }}$ of the produce had to be given to the king), Andeparaveni lands ( $1 / 2$ of the produce was paid to the king) and Ovitiparaveni or 
meadow lands.

The tenure 'ande' (share or sharecropping), takes greater contribution of all the cultivation practices of the country, which is derived from the terms of Sanskrit 'ardha' (half) and Sinhala ada (Sinhala Encyclopedia, 1956; 458). This tenancy practice differs from up country to low country, from the Wet zone to the Dry zone or sometimes from district to district and is widely prevalent in paddy cultivation. Ande is a certain type of share-cropping arrangement remnants of which could be still found in muttetu land belonging to old temples (Peiris, 2006; 215). Certain amount of the total harvest was divided by the land owner into four equal parts under the ande system.

During the Colonial period, the Dutch (1656 1796) had maintained a different tenure system known as land thombos (Land Thombos), which gave detailed description of land and gardens in each village specifying the high lands,lowlands, buildings, trees and tax dues and the list of persons which was known as head thombos (Head Thomos) together with the details of the dweller, sums due from each individual, with the age, occupation, taxes each had to pay. Some of the land tenure systems applied by the Dutch was derived from the systems adopted by local Kings. They successfully converted these systems into their own and collected revenue from land and services.

In 1796, the British introduced a new economic system as well as a new land tenure system for the country. The first principle was under developed land which was crown property. The second principle was that the initiative for the alienation of Crown land must come from the individual in need of the land and the third was that the Crown land must be paid for (Report of the Land Commission, 1987; 13-14). To achieve these objectives the Government enforced the Crown Land Encroachment Ordinance (CLEO) in 1840. According to the Ordinance all forest, waste, unoccupied or uncultivated lands shall be presumed to be the property of the Crown until the contrary was proved. However, those who were having tenure documents or evidence such as 'Sannas' or 'Grant' given by the Royalties, evidence of having paid taxes within at least two decades and proof of the maintenance of a plantation or other improvement for not less than three decades with uninterrupted possession throughout this period were exempted of the CLEO.

In 1856, Temple Land Registration Ordinance was enacted. The purpose of the Ordinance was the settlement of claims of exemption from taxation as temple land in the Kandyan provinces and for the due registration of all land belonging to such temples. According to 
the Land Commission Report, '..a total extent of approximately 72,845 ha. was claimed by the temples, where only about 32,375 ha. were granted registration as temple property. During the time of kings period about 323,755 ha.were exempted fix) state taxes (Land Commission Report, 1988; 161). The land included paddy, gardens, chenaor forests, which have been recorded neither on yield nor on productivity figures.

The three prominent customary laws that were inherited from the Roman-Dutch legal regimes in Sri Lanka were Kandyan law, a residual of ancient Sinhalese land tenure originating from the Aryans, Thesavalamai law applicable to the Tamils of Jaffna peninsula and the Muslim law (Shariya) of the Eastern province. At present, there are two major types of land regimes that can be identified in Sri Lanka i.e. Land control under State and Land control under the Private Sector or non-State control. The State land regime where the government retains absolute titles, such as lands under the Lands in custody of state corporations and departments, the tenure condition of which is neither private nor state.

The Kandyan customary law (Udarata law) associated land with marriage through deega (the wife lives with the husband's family) and binna (the husband lives with the wife's family). In binna, the wife enjoys absolute rights over her land and property and as folklore maintains, she can send back her husband whenever she so desired. In deega, brothers can share the same wife (ekageikaema), which prevailed until recent times, to avoid partitioning limited land. In such a situation, children were treated as those of a married person, but were brought under the care of all brothers (Sarwodaya, 2010).

It is evident that the customary practices still existing are Thattumaru (rotation of cultivation among several family members) in using land at different cultivation seasons, and Kattimaruwa is a rotation system of plots that allow a fallow period for soils to fertilize their soil in the Dry zone. The Thesavalamai customary law obliges a landowner to concur with adjoining landowners before executing a land sale or transfer. The law was applicable to Jaffna Tamils but it had unintended effects such as preventing other ethnic groups (Sinhalese and Muslims) from acquiring land.

Mukkuwar customary tenure system is one that persists among Muslims. Their marriage and family customs are directly related to property inheritance. The Muslim Intestate Law of Inheritance is one of the operational pieces of legislation that provides how land should be passed on to the next generation, with the belief that the "law of the god should take precedence over the law of the land", 
particularly where private freehold property is concerned.

It is useful to examine in detail the dynamism of customary land tenure of Sri Lanka taking into consideration the Viharagam and Devalegam system.

Outcomes: Dynamism of customary land tenure-Viharagam and Devalegam

Viharagam and Devalegam are an important tenure system that could be identified in the customary land tenure in Sri Lanka. Land given to religious institutions by the King are called Viharegam (given to Buddhist temple) and Devalegam (given to Hindu temple). The King granted the land to religious institutions with the entitlement of 'until the sun and the moon lasts' or 'given forever'. According to the Land Commission Report in 1987 there were some 800,000 acres $(323,760$ ha.) of land under Viharagam and Devalagam in Sri Lanka (Land Commission Report, 1987; 4). These lands come under the Muttettu land (See; Figure 01).

Muttettu land is the co-holder ship of land belonging to the officials and royal household temples. According to Abesinghe (1978), grantee of a village received not all the land in the village but only a portion of it set apart for the use of the holder which is called Muttettuland. Land controlled by temples or officials, Muttettu land (co-holdership with another institution), Nindamuttettu (sole ownership), Vidanemuuttettu (partial ownership), Andemuttettu (tenancy ownership), Koralegam (controlled by provincial leaders), and Saramarugam (given to those who served for king on temporary basis). The portion of yield or income of Muttetu land should have been returned to the landholder as a share by the land user. The share of the land users covered conducting yearly important events, maintaining the temple and other expenses occurred due to different activities of the temple. Land given to users under the customary system for short time basis have maintained a close relationship with the temple, which have been made stronger with their faith.

Under the Viharagam and Devalegam Ordinanance No 19 of 1931, Buddhist temporalities have authority to examine the management and developing issues connecting with the Viharagam and Devalagam lands. Among these lands the 'Paravenipangu' were divided among the people who served for those temples thereby being given coownership of those lands. During ancient times barter system came into existence according to which the duties were decided with the extent of task agreed where no one can change the assigned duties afterwards.

During the British period, the duties of 
Paraveni were valued at a certain amount of price. Those ancient prices have not changed at all even with the change of the era. Hence, the income earned by these being insufficient for proper maintenance of the Devala's and temple's day today functions in the present time.

Figure 03 illustrates a model of dynamism of customary land tenure practices in Sri Lanka. Field level experience revealed that the land under the customary tenure (Muttettu land) belongs to religious institutions like Temples and Devales and land given to individuals who gives a share of yield or income for the temple. Some of them follows and continue the customary agreement with the landowner (Temple or Devala) and individual land users while others do not. The Temples and Devales are not in a position to take legal measures against the acquired land for not fulfilling their duties entrusted due to legal assistance being too costly comparatively to the respective outcome of the duty. Land rights have been transferred to others in terms of pawn, lease, ande or other. The new landholder might return the share of land to the temple. Many temples have been questioning the issue and reaching for litigation process for acquiring their lands back. It was evident that some temples have granted pieces of land for charity such as construction or expanding the land areas of schools or community centers. Obtaining of licenses, permits and other documents for Devala and Temple land is a rigorous and time-consuming process. When contemplating the procedure, formal approval from Basnayaka Nilame is required first, followed by approval from the Commissioner of Buddhist Affairs. Obtaining a license to such a piece of property, on the other hand, is a lengthy process. In the long run, purchasers, sellers, investors, developers, and occupiers have some limitations to utilize the land due to legal barriers. In addition, there are no provisions for obtaining licenses in the event of property development/use, such as gem mining, construction, farming, and so fourth. Therefore, the number of encroachers and the people who utilize the land with unidentified (hidden) tenure are higher under the customary system.

Type of land tenure and land productivity (agricultural production) may have some relationship. Dharmasiri, (2009); Smith, (2004); Pritchard, (2013); Singirankabo and Ertsen, (2020); and World Bank (2020) have identified that the positive relationship between land tenure and land (Agricultural) productivity in the countries of Sri Lanka, Zambia, Ruwanda and Chad respectively. The present study was identified when the tenure security is weakened, the landholder (user) 
may not invest more money on improvement of land productivity in terms of using fertilizer or agro-chemicals and proper land management. Major agricultural activities of the lands are seasonal crops of paddy and permanent crops of coconut cultivation in the study area. It was evident that the land productivity of these land i.e. land given to individual cultivators and encroachers (See; Figure 03) whom have been utilizing the land with or without land tenure rights under the Viharagam and Devalegam system is comparatively low with other lands in the area.

\section{CONCLUSION}

Different communities, religious institutions and individuals have been practicing dissimilar customary land tenure systems in Sri Lanka. Most of these systems began in the Kings era thereby being transformed in to many different practices, yet nevertheless the core-principles of the particular system have not changed. The hypothesis of this study was that the "customary land tenure system is a static, but one that has been transforming into new order from time to time, thus the customary land tenure system is a dynamic process" which has been proven and further elaborated by the model of dynamism in customary land tenure.

The study has identified that there is a different relationship between tenure rights and land productivity (agricultural productivity) under the customary tenure system. When the tenure rights are tightening, the investment on the land will be high enabling more prospects comparatively to the poor tenure rights.

Population pressure on land has been increasing rapidly while unused, underutilized or potentially utilized for high returns, persists in Sri Lanka. Some of the land belonging to the Viharagam and Devalegam land are an example for this category. It has reached a point to find some alternative way in utilizing such land in order to enable maximum outcome against the burning issues of the country. Then the land productivity could be able to maximize and it will help to maintain sustainability at the micro level (land user). Further, it will help to maintain food security of the land users due to high outcomes of the land.

I acknowledge Ms. LND Liyanapatabandi, who has done a research on "Recent trends in land tenure on the Viharaand Devalegam: With reference to Nindagam of the Beligala temple in Sri Lanka" for the partial fulfilment of the Degree in Geography, at the Department of Geography, University of Kelaniya, Sri Lanka.

\section{REFERENCES}

[1] Ariyapala, M.B. (1956), Society in Medieval Ceylon, n/p. Colombo.

[2] Abeysinghe,, B.A (1978), Ancient Land 
Tenure to Modem Land Reform in Sri

Lanka. Vol, 1, The Centre for Society

and Religion, Colombo.

[3] Codrington, H.W. (1938), Ancient Land

Tenure and Revenue in Ceylon, Colombo.

[4] Dharmasiri, (2009) 'Land Use, Land Tenure and Agricultural Productivity in Sri Lanka: A Tempo-Spatial Analysis', A thesis submitted to the University of Pune for the degree of Doctor of Philosophy in Geography. Available on: http://hdl.handle.net/10603/175107 [accessed July 20 2021].

[5] FAO (2002) Land tenure and rural development, FAO Land Tenure Studies, Available on: http://pdf.wri.org/ref/fao_02 land tenur e.pdf[accessed Aug 02 2021].

[6] Mather, A.S. (1986), Land use. Longman, London

[7] Mahinda Silva, A.T. (1987), "The Evolution of Land Policies in Sri Lanka" Marga, Vol. 7, No, 01: 33-57.Perera 'Proprietary and Tenurial Rights in Ancient Ceylon'

[8] Pieris, Ralph (1956), Sinhalese Social Organization; TheKandyan Period. The Ceylon University, Press Board.

[9] Pritchard, M.F. (2013) Land, power and peace: Tenure formalization, agricultural reform, and livelihood insecurity in rural Rwanda. Land Use Policy, 30, 186-196. Available from: https://www.researchgate.net/publication /341127053 Relations between Land Tenure_Security and_Agricultural_Prod uctivity Exploring the Effect of Land Registration [accessed Aug 21 2021].

[10] Report of the Land Commission- 1987, Sessional Paper III-1990. Department of Government Printing, Colombo.

[11] Sarwodaya, (2010), Land Ownership and the Journey to Self-Determination, Sri Lanka Country Paper Land Watch Asia. Available on http://angoc.org/wpcontent/uploads/201 2/09/SriLanka_Country_Report2.pdf

[accessed July 12 2021].

[12] Sinhala Encyclopedia vol. I, (1958), Department of Cultural Affairs, Colombo.

[13] Silva, M.U. de (2000), Caste Feudalism of Sri Lanka, (in Sinhala) TharanjiPrinters, Maharagame.

[14] Singirankabo Alban, Uwacu, and Maurits Willem Ertsen. 2020. "Relations between Land Tenure Security and Agricultural Productivity: Exploring the Effect of Land Registration" Land 9, no. 5: 138. https://doi.org/10.3390/land9050138[ac 
cessed Aug 21 2021].

[15] Siriweera, W.I. (1994), The Theory of King's Ownership in Land; An Essay in Historical Revision. Ceylon Journal of Social and Historical Studies

[16]C.M. Thakar, S.S. Parkhe, A. Jain etal., 3d Printing: Basic principles and applications, Materials Today: Proceedings, https://doi.org/10.1016/j.m atpr.2021.06.272

[17]Khan, R. M. I., Kumar, T., Supriyatno, T., \&Nukapangu, V. (2021). The Phenomenon of Arabic-English Translation of Foreign Language Classes During The Pandemic. IjazArabi Journal of Arabic Learning, $4(3)$.

https://doi.org/10.18860/ijazarabi.v4i3.1 $\underline{3597}$

[18] Sajja, G., Mustafa, M., Phasinam, K.,Kaliyaperumal, K., Ventayen, R., \&amp; Kassanuk, T. (2021). Towards Application of Machine Learning in Classification and Prediction of Heart Disease. 2021 Second International Conference On Electronics And Sustainable Communication Systems (ICESC).https://doi.org/10.1109/icesc5

\section{$\underline{1422.2021 .9532940}$}

[19] Veluri, R., Patra, I., Naved, M., Prasad, V.,Arcinas, M., Beram, S., \&amp;
Raghuvanshi, A. (2021). Learning analytics using deep learning techniques for efficiently managing educational institutes. Materials Today:Proceedings. https://doi.org/10.1016/j.matpr.2021.11. $\underline{416}$

[20]Smith, R.E. Land tenure, fixed investment, and farm productivity: Evidence from Zambia's Southernprovince. World Dev.2004,32, 1641-1661. Available on: https://www.worldbank.org/en/results/2 020/11/10/land-tenure-matters-foragricultural-productivity-in-chad [accessed Aug 21 2021].

[21] World Bank (2020), Land Tenure Matters for Agricultural Productivity in Chad. Available on https://www.worldbank.org/en/results/2 $\underline{020 / 11 / 10 / 1 a n d-t e n u r e-m a t t e r s-f o r-~}$ agricultural-productivity-in-chad. [accessed Aug 21 2021]. 


\section{Ancient customary land tenure in Sri Lanka}

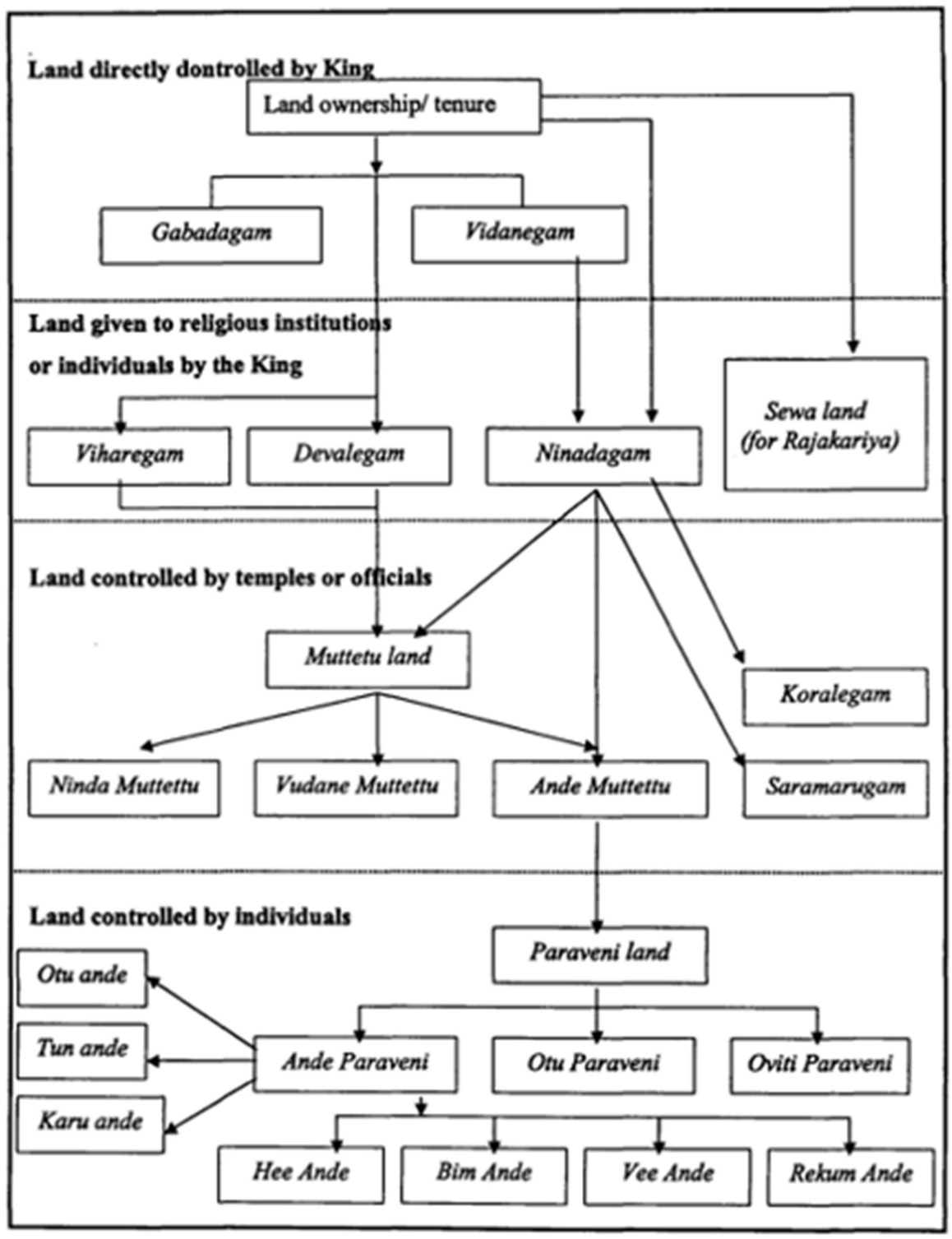

Source: Dharmasiri, 2009

Figure 01 
Present customary land tenure in Sri Lanka|

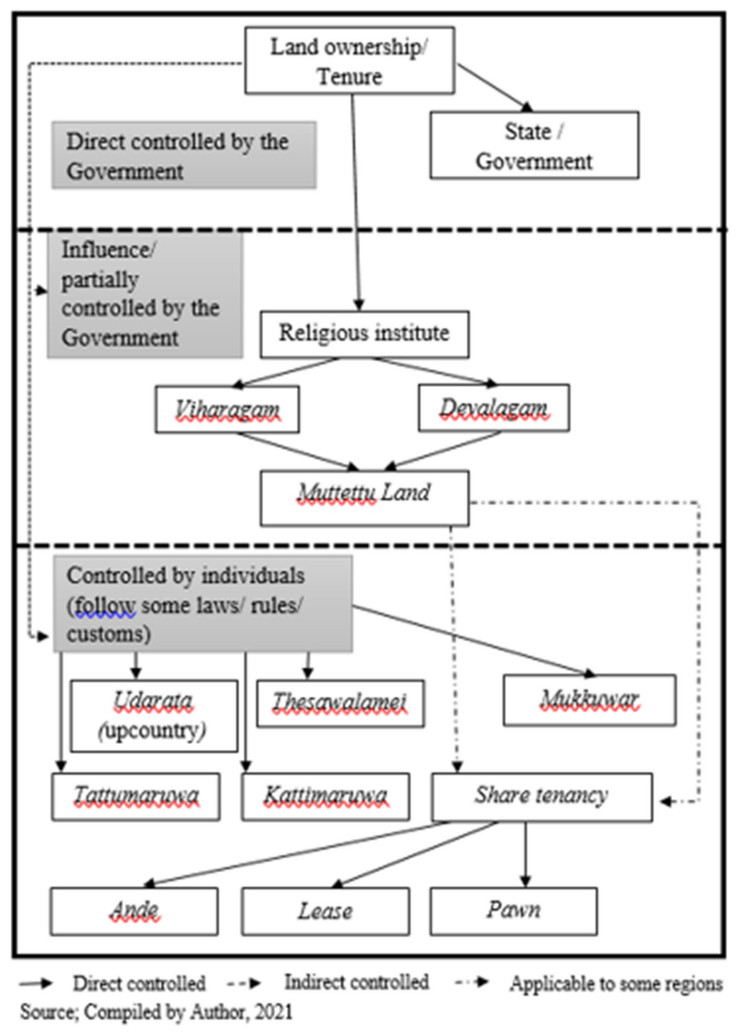

Figure 02:

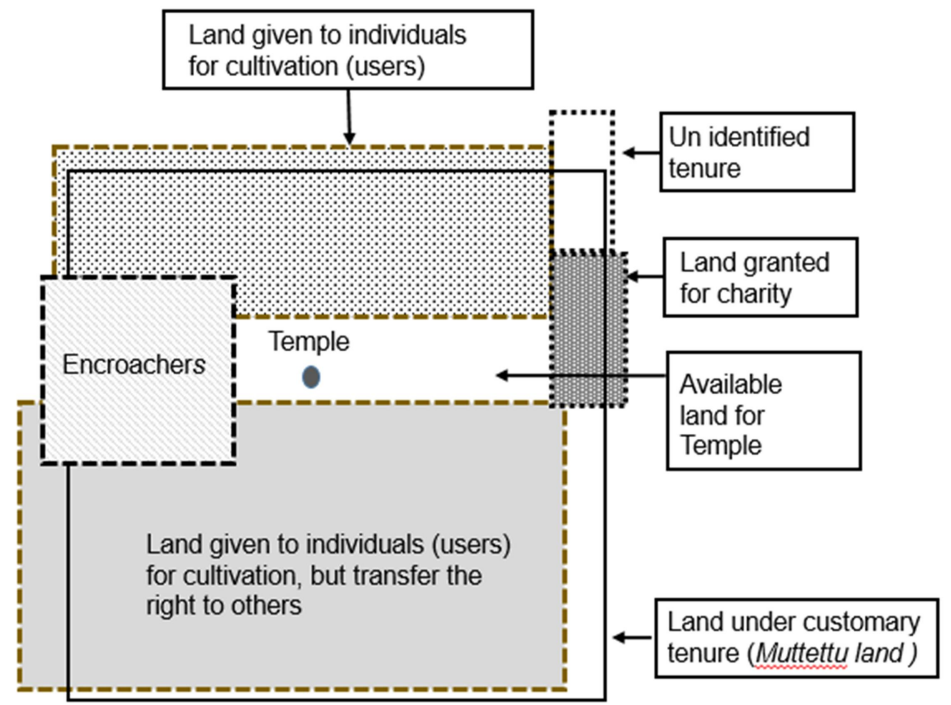

Source; Developed by Author

Figure 03: A model of dynamism of customary land tenure 